\title{
Are You Flippin' the Classrooms Right - A Requirements Analysis of Two User Groups: Practitioners and Students
}

\author{
Jörg H. Mayer \\ Darmstadt \\ University of Technology \\ jhmayer@t-online.de \\ Nadja Scholl \\ Frankfurt \\ nadja.scholl@online.de
}

\author{
Sanjar Sayar \\ Darmstadt \\ University of Technology \\ sayar@bwl.tu-darmstadt.de \\ Reiner Quick \\ Darmstadt \\ University of Technology \\ quick@bwl.tu-darmstadt.de
}

\author{
Maren Wienand \\ University of \\ Duisburg-Essen \\ mareen.wienand@icb.uni-due.de
}

\begin{abstract}
By inverting the knowledge transfer, flipped classrooms promise a richer learning experience and an enhanced learning process. The objective of this article is to contribute to more user-centric flipped classroom trainings by developing a list of requirements criteria from the participants' perspective. We take an SAP S/4 HANA lecture at a university as our case example and consider two types of learners for the same training, that is practitioners and students. Significant differences emerged. For example, practitioners cherished self-contained learning at their own pace whereas most of the students asked for motivated lecturers to give direction. Our results are clustered threefold: (1) User perception - getting the method right is as important as the content; (2) Lecturer - developing soft skills beyond mere knowledge transfer; (3) Technology - setting the scene properly when rotating to the $N E W$.
\end{abstract}

\section{Introduction}

E-learnings which are defined as the "asynchronous delivery of educational materials [...] enabled by network technology" [1] are available anytime at the computer. Therefore they go beyond face-to-face classroom approaches (and even online lectures) where lecturers instruct in person and real time.

E-learnings are underrepresented [2]. However, given the rising preference for asynchronous online media consumption, a trend towards e-learnings cannot be ignored [3]. Furthermore, the current COVID-19 pandemic is clearly accelerating its evolution.

Besides e-learnings there are different formats of so-called blended learning. Combining the best of both worlds, they integrate traditional face-to-face interactions in classrooms with flexible scheduling and self- paced (even asynchronous) e-learning that take place online [4].

A newer format of blended learning are flipped classroom trainings - also known as inverted or reversed classrooms [5]. Here, the knowledge transfer is inverted. Accommodating participants' own pace, the individual learning occurs online, prior, and outside the classroom. The group learning takes place later as the participants share and discuss their (new) knowledge with the lecturer and classmates - often retaining faceto-face contact in the classroom [6]. Applying such a method mix, flipped classrooms promise a richer learning experience and an enhanced learning process [7].

Research on flipped classroom trainings is in its infancy. We found few articles such as Kwon and Woo [8] examining requirements that cover both the expectations of the participants before the training and their experience with the training afterwards. Furthermore, articles such as Steinbeck [2] deal with content, learning elements, and capabilities of lecturers. However, a rigorous requirements analysis is missing. Furthermore, most articles focus solely on students and only a few articles like Alali [9] examine flipped classrooms for practitioners. Consequentially, we found no article challenging the same flipped classroom training attended by different groups of learners.

Therefore, the objective of this article is to contribute to more user-centric flipped classrooms by developing a list of requirements criteria from the perspective of different groups of learners. We take an SAP S/4 HANA lecture from blinded for review University of Technology as our case example and distinguish between two types of learners in the same training, that is practitioners and students. Furthermore, we examine both their expectations before the training and their experience with the training afterwards. 
To create things that serve human purposes [10], ultimately to create a better world [11], we follow Design Science Research (DSR) in Information Systems (IS, [12, 13]). The publication schema by Gregor and Hevner [14] gave us direction: We motivate this article on the basis of current gaps regarding flipped classrooms (introduction). Based on the state of the art, we highlight research gaps (literature review). Addressing these gaps, we analyze differences between practitioners' and students' requirements criteria in one and the same training and we do that before and after the training (met$h o d)$. As a result, we come up with a list of requirements criteria (artefact description). Emphasizing a staged research process with iterative "build" and "evaluate" activities [15], we finally review the results with the participants of the training (evaluation). Comparing these results with prior work and examining how they relate back to the article's objective, we end with a summary, consider the limitations of our work, and suggest avenues for future research (discussion and conclusion).

\section{Literature review}

We started our literature review with a (1) journal search focusing on leading IS ${ }^{1}$ and educational journals ${ }^{2}$ complemented by proceedings from major IS conferen$\operatorname{ces}^{3}$ [18]. Since our subject of research is also of practical interest, we looked at MIS Quarterly Executive and Harvard Business Review. For our (2) database search, we used Science Direct, EBSCOhost, Springer Link, AIS eLibrary, and Google Scholar.

Assessing the publications by their titles, abstracts, and keywords, we performed an iterative (3) keyword search. Starting with "flipped (or inverted) classroom training," our research led to more than 1,300 hits (Figure 1). We restricted this number of articles by "requirements" or "requirements analysis." This led to 14 hits. Regarding the practitioner perspective, we found four publications relevant namely Davies [19], Flipped Learning Network [20], Panopto [21], and Yale Poorvu Center for Teaching and Learning [22].

Finally, we conducted a (4) backward and forward search. Following the citation pearl growing approach, we specified our search whenever we examined new relevant aspects in the retrieved publications [23]. Considering references from all relevant publications, we identified another 25 articles. With these results, we ended up with 43 publications in total. Figure 1 depicts our search string with the number of relevant publications in black ovals.

Requirements can be defined as prerequisites, conditions, or capabilities needed by individuals or systems to solve a problem or achieve an objective [24]. Ensuring that our list of requirements criteria is distinct, collectively exhaustive, and preventing a faulty design, we follow requirements engineering. It aims at increasing the quality of our model development by a systematic procedure for collecting, structuring, and documenting requirements as follows [24]:

The first phase "requirements identification" is about scoping our training. Here, our focus is on the different two groups of learners. In doing so, we examined 36 articles about students participating in flipped classrooms. In turn, there are only seven articles addressing practitioners (defined as non students). For example, Nederveld and Berge [25] lay out that in flipped classrooms participants can learn at their own pace. Thus, lecturers can support a diverse group of participants more

Number of relevant publications [n=43]
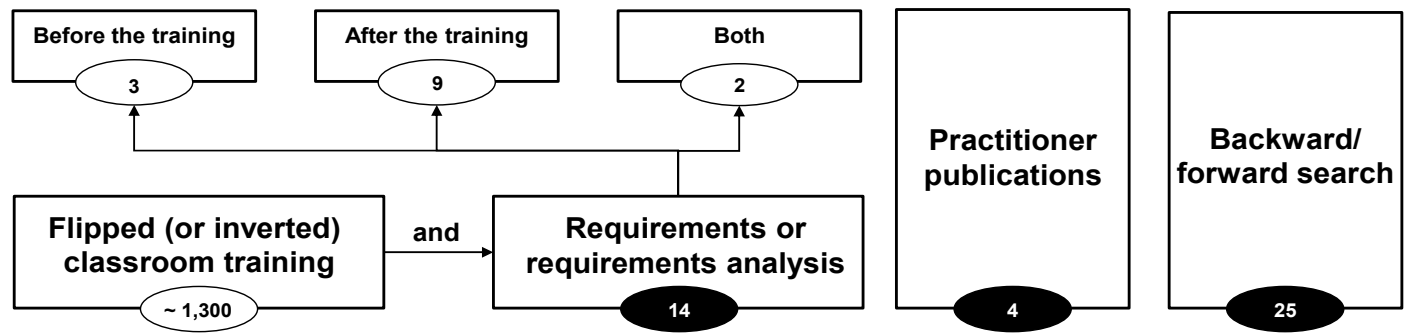

Figure 1. Search strategy within our citation pearl growing approach.

\footnotetext{
${ }^{1}$ We followed the AIS [16] and their senior scholars' basket of leading IS journals: European Journal of Information Systems; Information Systems Research; Information Systems Journal; Journal of the Association for Information Systems; Journal of Information Technology; Journal of Management Information Systems; Journal of Strategic Information Systems; MIS Quarterly.
}

\footnotetext{
${ }^{2}$ We considered as follows: Educational Sciences: Theory \& Practice; The Journal of Educational Technology \& Society; The Electronic Journal of e-Learning; Journal of Information Systems Education. ${ }^{3}$ We followed the AIS [17] and their list of leading IS conferences: Americas Conference on Information Systems; European Conference on Information Systems; International Conference on Information Systems; Pacific and Asia Conference on Information Systems.
} 
easily. Alammary et al. [3] expose that flipped classroom trainings should combine several types of learning approaches and the applied materials should be a mix virtual elements such as e-books, video tutorials, and click-through demos which the participants can choose by themselves.

While students primarily start from scratch with the content and draw on it to pass an examination, practitioners often have experience in applying the learning content and want to ask questions and comment especially from their work in detail.

We only found two articles which address both kinds of flipped classroom learners. Loukis et al. [26] developed a multi-perspective e-learning evaluation and did so not only for university students, but for practitioners as well. In line with Lokman et al. [27], who point out that few articles deal with flipped classrooms in both environments of university and practice, we address this first research gap by offering the same training to practitioners and students. We do that in order to receive their individual feedback, finally, in the expectation of revealing differences in their answers.

In the second phase, requirement analysis and specification, the criteria have to be put into a standard form covering predefined attributes for each criteria. Furthermore, the list of criteria should be prioritized [28]. Following Alammary [5], we differentiate our work threefold: (a) Regarding practitioners' and students' individual user perception, we examined ten articles. Roehling [29] lays out an "[...] emerging evidence that flipped learning may be more effective [...] when promoting $[\ldots]$ individual self-regulation, community building, engagement, academic and interpersonal skills." (b) Twenty-one articles are about requirements criteria regarding lecturers. Covering a new learning and teaching experience with fun and enjoyment, Alammary [3] conducted a study which examines community building and new interactions in virtual classrooms. (c) Twelve articles are about technology with a focus on quality and ease of use. Other articles focus on a new amount of information delivered by new technologies. For example, Bicen and Taspolat [30] obtained students experiences with classes that are supported by social media.

Furthermore, three articles obtain participants' requirements by investigating their expectations before the training whilst nine articles collect requirements afterwards. For example, Coady and Berg [31] conducted a qualitative study after a course, asking students about the fulfillment of their requirements. Only, Blair et al. [32] as well as Kwon and Woo [8] carried out a requirements analysis before and after a training. We address this second gap of research by a comprehensive list of requirements criteria examining participants' expectations before our training and their experience after the training.
During the third phase, requirements validation, a decision is made which requirements should be considered in the subsequent list. Especially the training participants must reach a consensus whether the requirements criteria effectively represent their expectations [24]. Sixteen articles provide literature reviews. Another thirteen test hypotheses in case studies and focus group embracing observations and interviews (qualitative research). Fourteen articles apply quantitative research. For example, Schenk and Hoxhaj [4] applied a method mix and examined that students are open to the idea of blended learning, but their motivation drops during the course. However, only few articles opt for a method mix. We mitigate this third and final gap research gap with a method mix [33] of a survey-based requirements analysis (quantitative research, Sect. 4) and discussing the results with the participants afterwards (qualitative research, Sect. 5).

\section{Method}

We opted for a case study and set up a questionnaire based on SoSci Survey [34]. Based on the findings from our literature review (Sect. 2), we came up with a list of requirements criteria (Sect. 3.1) and consolidate the results considering even free text comments (Table 2).

Examining the consistency of the questionnaire [35], we calculated Cronbach's alpha for (1) the sample of participants per se (0.80) and each group: Practitioners (0.71) and students (0.81). According to Streiner [36], values above 0.7 are good and above 0.8 are very good. Thus, all values confirm at least a good consistency of our questionnaire and that each component is a part of the general performance construct.

\subsection{Questionnaire}

After explaining the participants' rights regarding confidentiality, the main part of our questionnaire contained one item for choosing the time before and after the training and twelve requirements criteria for flipped classrooms to be evaluated on a five-point Likert-scales ranging from " 1 = very low to $5=$ very high." For comments, we offered free text spaces at each requirements criterion. With age, education, and gender, the final part of the questionnaire records demographic data to better understand participants' decisions concerning our requirements criteria. This includes two "yes/no" questions about participants' experience with e-learnings and flipped classrooms in particular and we asked a final question about their IT expertise (five-point Likert scale).

The main part of the questionnaire contained three sections (Sect. 2). Focusing on participants' user perception, individual pace of learning should play a major role for performing flipped classroom training sessions 
successfully (\#1, "I can determine my own speed of learning (Table 2)" [32]. Self-contained learning considers the growing need for more flexibility in taking the time to learn (\#2, "I can learn self-contained." [9]). Students typically learn essentially to pass an examination. In turn, practitioners want to ask questions arising from their work (Sect. 2). Thus, balancing overview knowledge and details should keep the participants stay motivated (\#3, "I receive a mix of overview and details." [37]). A variety of learning materials are important for flipped classroom trainings as well (\#4, "I receive various kinds of learning materials.").

Being able to select most important (exam-relevant) information easily influence participants purposeful learning (\#5, "I am able to differentiate between most important (exam-relevant) and complementary information." [38]). Motivation declines as a course proceeds (Sect. 2). Following Mok [39], working continuously over the training is another requirements criterion (\#6, "I work continuously over the whole training and will stay motivated."). In flipped classrooms it is difficult to ensure an adequate level of interaction. Therefore, a final requirements criterion for participants' perception of flipped classrooms are social bondages within a community (\#7, "I am part of a community." [40]).

The second sub section covers the lecturer. Due to information asymmetry with respect to the participants, lecturers must balance the situation. If they are very convinced of themselves and show it excessively, it is likely that they appear arrogant. Those who are too relaxed will appear bored to their participants [9]. Accordingly, another requirements criterion is lecturers' motivation (\#8, "A motivated lecturer is important to me."). They also have to project their motivation on participants (\#9, "It is important that the lecturer motivates me." [32, 37]. Integrating comments from learners in the training is another challenge (\#10, "It is important for me that the lecturer notices me." [32]).

The third sub section addresses the supporting technology. Availability and bandwidth is a yardstick and defines IT quality (\#11, "IT quality is important for me." [41]). Finally, smooth and easy IT access might be important as well (\#12, "IT ease of use is important to me." [42]).

\subsection{Analysis}

We calculated arithmetic means (AM) for each requirements criterion, and we did that for two points of time before the training and afterwards. Furthermore, we did so for the (a) complete group of the participants as well as for (b) practitioners and (c) students separately. The arithmetic means are complemented by standard deviations (SD).

Key statements from analyzing the free text fields and from the qualitative analysis make these figures more tangible. Furthermore, we conducted $t$-tests to find out twofold whether the results differ significantly between each group or before and after the training $\mathrm{p} \leq 5 \%$ (*) or very significantly $\mathrm{p} \leq 1 \%(* *)$.

Regarding our proposed method mix (Sect. 2) the quantitative statistical results cover the rigorous factdriven points for discussion whilst qualitative feedback should make the take aways more concrete. Consequently, we reviewed the survey results with the training participants in a feedback session which took place after the training on June 25, 2020 (Sect. 5). Demographic data were examined to better classify participants' decisions and comments concerning our requirements criteria.

The training took place between May 8, 2020 and June 18, 2020 with online classroom session every two weeks. We asked the participants to complement the questionnaire as follows: (1) Directly after introducing the training on May 8, 2020, they were asked on the five-point Likert scale about their expectations: "How important should the following requirements criteria be?" (2) The second time was after the final session on June 18, 2020. Anticipating changes, we asked participants about the fulfillment of their expectations after the training: "How important were the requirements criteria?" Table 1 summarizes the characteristics of the data sample.

\begin{tabular}{|c|c|c|c|c|c|}
\hline Field of study & No. & {$[\%]$} & Age & No. & [\%] \\
\hline Industrial Engineering & 16 & 55 & $<25$ years & 13 & 46 \\
\hline Business Administration \& Economics & 5 & 17 & $26-30$ years & 8 & 27 \\
\hline Information Systems & 6 & 21 & $31-35$ years & 0 & 0 \\
\hline Others & 2 & 7 & $>35$ years & 8 & 27 \\
\hline Previous experiences with e-learning & No. & {$[\%]$} & Participant category & No. & {$[\%]$} \\
\hline No & 2 & 10 & Practitioners & 8 & 28 \\
\hline Yes & 27 & 90 & Students & 21 & 72 \\
\hline $\begin{array}{l}\text { Experiences with flipped classroom } \\
\text { trainings }\end{array}$ & No. & {$[\%]$} & \multirow[t]{3}{*}{ Total } & \multirow[t]{3}{*}{29} & \multirow[t]{3}{*}{100} \\
\hline No & 26 & 90 & & & \\
\hline Yes & 3 & 10 & & & \\
\hline
\end{tabular}

Table 1. Characteristics of survey participants. 


\section{Artefact Description}

Starting with the list of prioritized requirements criteria, they are listed in the order in which they were asked in the questionnaire (Table 2, column 1). The second and third column show their AM before and after the training (SD in brackets). The results from our t-tests are summarized in column 4 .

\subsection{User Perception}

The first requirements criterion "I can determine my own pace of learning" was considered as important before the training (AM: 4.24 (SD:.69); practitioners: 4.38/.52); students: 4.19/.75) and even more important after the training (4.45/.57; practitioners: $4.88 / .35$; students $4.29 / .56)$. For practitioners we observed a significant difference between the two point in times $(\mathrm{t}=-$ $\left.2.26^{*}\right)$. Furthermore, we observed a very significant difference between practitioners (4.88) and students (4.29) after the training $\left(\mathrm{t}=-2.75^{* *}\right)$.

With the same prioritization, practitioners highlighted "self-contained learning" before and after the training (.35). One participant commented that this second requirements criterion accomplishes the need for flexibility best. The t-test revealed a very significant difference between practitioners and student evaluations before the training ( 4.88 vs $\left.3.95 / .74 ; \mathrm{t}=-3.36^{* *}\right)$ as well as a significant difference after the training (4.88 vs $\left.4.43 / .68, \mathrm{t}=-1.76^{*}\right)$ as students significantly $\left(\mathrm{t}=-2.18^{*}\right)$ shifted their evaluation from 3.95/.74 towards 4.43/.68.

Interpreting these results, students are used to organize themselves, although some of them do not learn continuously during the training - particularly when the exam is "sometime in the future." These students had not understood that flipped classrooms are facilitated by their own questions and comments (Sect. 1, 2). By contrast, practitioners were more motivated in general and focus most often on asking questions arising from their work. However, we conclude that participants' individual commitment is lower with virtual classroom than in a traditional face-to-face classroom.

Balancing the mix of overview knowledge and details should help participants to remain motivated. Especially students should not be overwhelmed by too many details. However, some students asked for more relevant use cases presented with a touch of entertainment. This third requirements criterion was evaluated at 4.07/.92 before the training (practitioners: 4.38/1.06; students: $3.95 / .86$ ) and after the training at 4.14/.96 (practitioners: 4.25/.46; students: 4.50/1.09). Before the training, practitioners rate the right mix of an overview and details very significantly $\left(\mathrm{t}=-3,36^{* *}\right)$ more important than stu- dents. One participant commented that it is a prerequisite for a good training. The mix should be selected by the lecturers as they know their materials best.

Different kinds of learning material for the same content are conducive to the motivation of learners. This fourth requirements criterion achieved a good rating of 4.07/.70 before the training (practitioners: $4.25 / .71$; students: $4.00 / .71$ ) and after the training of 4.07/1.07 (practitioners: $4.50 / .63$; students: $3.90 / 1.18$ ) as well. Three participant suggested introducing some "fun and competition" by integrating game-based learning units such as Kahoot.

The ability to differentiate between important and unimportant information was rated quite low before and after the training $(3.54 ; 3.83)$. Working continuously over the course and remaining motivated was ranked second lowest by the practitioners before the training (2.86/.69). That changed significantly $(\mathrm{t}=-3,04 * *)$ after the training $(4.00 / 1.10)$. By contrast, the student ranking remained constant $(3.48 / .98 ; 3.75 / 1.16)$. We conclude that individual participant commitment is lower with virtual classrooms than in a face-to-face classroom. Accordingly, one comment was that online sessions should be quite short. Another comment wanted to consider interaction with break-out sessions with smaller groups and to share the results with the classmates.

"Being part of a community," our seventh and final requirements criterion of participants' user perception, was evaluated low (flop 1, Table 2) - before the training (3.07/1.07; practitioners: 3.13/.83; students: 3.05/1.16) and less important after the training $(2.86 / 1.19$; practitioners: $3.13 / .83$; students: $2.76 / 1.30$ as the lowest evaluation of the survey overall). A free-text comment suggested that seeing each other makes flipped classrooms more interactive, and binding.

\subsection{Lecturer}

"Motivated lecturers are important to me" was rated extraordinarily high from all participants before the training (4.62/.56, top 1 of the survey overall; practitioners: $4.50 / .53$; students: $4.67 / .58$ as second highest in our survey). One student commented: "A motivated lecturer motivates me and give trainings a basisc structure." However, the importance of this requirements criterion decreased after the training towards 3.93/.96 (practitioners: 4.13/.99; students: $3.86 / .96$ ). With a focus on students, we report a significant decrease to 3.86 after the training $\left(\mathrm{t}=3.30^{* *}\right)$. The same we revealed for "to me it is important that lecturers motivate me." This criterion was rated important before the training with a value of 4.31/.85 (practitioners: 4.13/.83; students: $4.38 / .86$ ). Afterwards, this criterion is $3.69 / 1.00$ (practitioners 4.00 / .53; students: $3.57 / 1.12$ ). Here, student perceptions decreased significantly $(\mathrm{t}=2,62 * *)$. 
Table 2. Results of our survey before and after the training.

\begin{tabular}{|c|c|c|c|}
\hline $\begin{array}{l}\text { Prioritized requirements } \\
\text { criteria }\end{array}$ & $\begin{array}{l}\text { (1) BEFORE training } \\
\text { arithmetic mean } \\
\text { (standard deviation) }\end{array}$ & $\begin{array}{l}\text { (1) AFTER training } \\
\text { arithmetic mean } \\
\text { (standard deviation) }\end{array}$ & $\begin{array}{c}\text { T-tests (one sided) } \\
* \text { significant: } p \leq 5 \% \\
* * \text { very significant: } p \leq 1 \%\end{array}$ \\
\hline \multicolumn{4}{|l|}{ Part 1: User perception } \\
\hline $\begin{array}{l}\text { 1. I can determine my own pace } \\
\text { of learning }\end{array}$ & $\begin{array}{l}4.24_{(0.69)} \\
\text { - Practitioners: } 4.38_{(0.52)} \\
\text { - Students: } 4.19_{(0.75)}\end{array}$ & $\begin{array}{l}\text { 4.45 Top } 3 \text { (0.57) } \\
\text { - Practitioners: } 4.88 \text { (0.35) } \\
\text { - Students: } 4.29_{(0.56)}\end{array}$ & $\begin{array}{l}\text { Significant difference } \\
\text { between practitioners } \\
\text { perspectives before and } \\
\text { after training }\left(\mathrm{t}=-2.26^{\star}\right) \\
\text { Very significant difference } \\
\text { between practitioners and } \\
\text { students after training } \\
\left(\mathrm{t}=-2.75^{\star \star}\right)\end{array}$ \\
\hline 2. I can learn self-contained & $\begin{array}{l}4.21(0.77) \\
\text { - Practitioners: } 4.88(0.35) \\
\text { - Students: } 3.95(0.74)\end{array}$ & $\begin{array}{l}\mathbf{4 . 5 5} \text { Top } 2(0.63) \\
\text { - Practitioners: } 4.88(0.35) \\
\text { - Students: } 4.43(0.68)\end{array}$ & $\begin{array}{l}\text { Very significant difference } \\
\text { between practitioners and } \\
\text { students before the training } \\
\left(\mathrm{t}=-3.36^{\star \star}\right) \text { and significant } \\
\text { difference after the training } \\
\left(\mathrm{t}=-1.76^{\star}\right) \\
\text { Significant difference bet- } \\
\text { ween students } \text { perspec- } \\
\text { tives before and after the } \\
\text { training }\left(\mathrm{t}=-2.18^{*}\right)\end{array}$ \\
\hline $\begin{array}{l}\text { 3. I receive a mix of overview } \\
\text { and details }\end{array}$ & $\begin{array}{l}4.07_{(0.92)} \\
\text { - Practitioners: } 4.38(1.06) \\
\text { - Students: } 3.95_{(0.86)}\end{array}$ & $\begin{array}{l}4.14_{(0.95)} \\
\text { - Practitioners: } 4.25(0.46) \\
\text { - Students: } 4.00_{(1.09)}\end{array}$ & $\begin{array}{l}\text { Very significant difference } \\
\text { between practitioners and } \\
\text { students before the training } \\
\left(\mathrm{t}=-3.36^{\star \star}\right)\end{array}$ \\
\hline $\begin{array}{l}\text { 4. I receive different kinds of } \\
\text { learning materials }\end{array}$ & $\begin{array}{l}4.07 \text { (0.70) } \\
\text { - Practitioners: } 4.25(0.71) \\
\text { - Students: } 4.00(0.71)\end{array}$ & $\begin{array}{l}4.07_{(1,07)} \\
\text { - Practitioners: } 4.50_{(0.53)} \\
\text { - Students: } 3.90_{(1.18)}\end{array}$ & $\begin{array}{l}\text { Insignificant differences } \\
\text { between practitioners and } \\
\text { students as well as before } \\
\text { and after the training }\end{array}$ \\
\hline $\begin{array}{l}\text { 5. I am to able to differentiate } \\
\text { between important and } \\
\text { unimportant information }\end{array}$ & $\begin{array}{l}3.54(1.07) \\
\text { - Practitioners: } 3.88(0.99) \\
\text { - Students: } 3.40_{(1.10)}\end{array}$ & $\begin{array}{l}3.83_{(0.93)} \\
\text { - Practitioners: } 3.63_{(1.19)} \\
\text { - Students: } 3.90_{(0.83)}\end{array}$ & $\begin{array}{l}\text { Insignificant differences } \\
\text { between practitioners and } \\
\text { students as well as before } \\
\text { and after the training }\end{array}$ \\
\hline $\begin{array}{l}\text { 6. I work continuously over the } \\
\text { whole course and will stay } \\
\text { motivated }\end{array}$ & $\begin{array}{l}3.32 \text { (0.94) } \\
\text { - Practitioners: } 2.86(0.69) \\
\text { - Students: } 3.48(0.98)\end{array}$ & $\begin{array}{l}3.59_{(1.09)} \\
\text { - Practitioners: } 4.00_{(1.10)} \\
\text { - Students: } 3.75_{(1.16)}\end{array}$ & $\begin{array}{l}\text { Very significant difference } \\
\text { between practitioners } \\
\text { perspective before and } \\
\text { after the training }\left(\mathrm{t}=-3.04^{* \star}\right)\end{array}$ \\
\hline 7. I am part of a community & $\begin{array}{l}3.07(1.07) \\
\text { - Practitioners: } 3.13(0.83) \\
\text { - Students: } 3.05(1.16)\end{array}$ & $\begin{array}{l}\text { 2.86 Flop } 1 \text { (1.19) } \\
\text { - Practitioners: } 3.13(0.83) \\
\text { - Students: } 2.76_{(1.30)}\end{array}$ & $\begin{array}{l}\text { Insignificant differences } \\
\text { between practitioners and } \\
\text { students as well as before } \\
\text { and after the training }\end{array}$ \\
\hline \multicolumn{4}{|l|}{ Part 2: Lecturer } \\
\hline $\begin{array}{l}\text { 8. Motivated lecturers are } \\
\text { important for me }\end{array}$ & $\begin{array}{l}\mathbf{4 . 6 2} \text { Top } 1 \text { (0.56) } \\
\text { - Practitioners: } 4.50(0.53) \\
\text { - Students: } 4.67(0.58)\end{array}$ & $\begin{array}{l}3.93_{(0,96)} \\
\text { - Practitioners: } 4.13_{(0.99)} \\
\text { - Students: } 3.86_{(0.96)}\end{array}$ & $\begin{array}{l}\text { Very significant difference } \\
\text { between students' per- } \\
\text { spectives before and after } \\
\text { the training }\left(t=3.30^{\star *}\right)\end{array}$ \\
\hline $\begin{array}{l}\text { 9. It is important for me that } \\
\text { lecturers motivate me }\end{array}$ & $\begin{array}{l}4.31_{(0.85)} \\
\text { - Practitioners: } 4.13(0.83) \\
\text { - Students: } 4.38(0.86)\end{array}$ & $\begin{array}{l}3.69_{(1.00)} \\
\text { - Practitioners: } 4.00(0.53) \\
\text { - Students: } 3.57_{(1.12)}\end{array}$ & $\begin{array}{l}\text { Very significant difference } \\
\text { between students' per- } \\
\text { spectives before and after } \\
\text { the training }\left(\mathrm{t}=2.62^{* \star}\right) \text {. }\end{array}$ \\
\hline $\begin{array}{l}\text { 10. It is important for me that } \\
\text { lecturers notice me }\end{array}$ & $\begin{array}{l}\text { 3.00 FLOP } 2 \text { (1.25) } \\
\text { - Practitioners: } 3.38(1.06) \\
\text { - Students: } 2.86(1.31)\end{array}$ & $\begin{array}{l}\text { 3.03 FLOP } 3 \text { (1.52) } \\
\text { - Practitioners: } 3.63(0.92) \\
\text { - Students: } 2.81(1.66)\end{array}$ & $\begin{array}{l}\text { Insignificant differences } \\
\text { between practitioners and } \\
\text { students as well as before } \\
\text { and after the training }\end{array}$ \\
\hline \multicolumn{4}{|l|}{ Part 3: Technology } \\
\hline 11. IT Quality is important for me & $\begin{array}{l}4.38_{(0.82)} \\
\text { - Practitioners: } 4.38_{(1.25)} \\
\text { - Students: } 4.38_{(0.74)}\end{array}$ & $\begin{array}{l}4.21_{(0.90)} \\
\text { - Practitioners: } 4.25_{(1.25)} \\
\text { - Students: } 4.19_{(0.71)}\end{array}$ & \multirow[t]{2}{*}{$\begin{array}{l}\text { Insignificant differences } \\
\text { between practitioners and } \\
\text { students as well as before } \\
\text { and after the training }\end{array}$} \\
\hline $\begin{array}{l}\text { 12. IT ease of use is important } \\
\text { for me }\end{array}$ & $\begin{array}{l}4.21_{(0.77)} \\
\text { - Practitioners: } 4.38{ }_{(0.74)} \\
\text { - Students: } 4.14_{(0.79)}\end{array}$ & $\begin{array}{l}3.93_{(1.00)} \\
\text { - Practitioners: } 4.00_{(1.07)} \\
\text { - Students: } 3.90_{(1.00)}\end{array}$ & \\
\hline
\end{tabular}


With a value of 2.86 before and 2.81 after the training, it is not really important for students that lecturers pay attention to them. However, the two SD imply different answers $(1.31 ; 1.66)$. An interpretation is "be online, but with no spotlight on me, so I can stay passive." In turn, practitioners want to ask questions, discuss their topics, and evaluated this criterion with an AM of 3.38/ 1.06 before the training and 3.63/.92 afterwards

\subsection{Technology}

The participants have experienced e-learnings (yes: $90 \%$, no: $10 \%$ ) and flipped classroom trainings (10, 90 $\%$ ) differently. We assume they step into flipped classroom trainings without prejudice regarding IT availability and bandwidth. They evaluated IT quality important before the training (4.38/.82; practitioners: 4.38/1.25; students 4.38/.74) and afterwards (4.21/.90; 4.25/1.25; 4.19/.71). Our twelfth and final requirements criterion, IT ease of use had also been rated important before the training with a value of 4.21/.77 (practitioners: 4.38/.74; students: $4.14 / 0.79$ ) and afterwards at 3.93/1.00 (practitioners 4.00/1.07; students 3.90/1.00).

Accordingly, IT is a prerequisite for performing flipped classrooms successfully. Practitioners evaluated IT somewhat lower after the training (\#11: from 4.38 to 4.25 ; \#12: 4.38 to 4.00 ). Students perceived the IT quality as ranging from 4.38 to 4.19 (\#11) and from 4.14 to 3.90 (\#12). With our survey, we found that this evaluation is not determined by age. Almost a third of our participants $(27 \%)$ were older than 35 and four participants older than 50 . With regard to lecturers, we propose that they need to anticipate any IT incident before the training and conduct a number of test runs. In the spirit of these results, lecturers should have a tech-savvy colleague in the backup to support them.

\section{Evaluate}

Emphasizing a staged research process (Sect. 1) and performing our mixed method approach (Sect. 2), we discussed the results from our survey (Sect. 4) with the participants of the training. We started with the completeness of our requirements criteria (Table 3 ). Conducting "deep dives" into the most important results of the survey such as self-contained learning (\#2) or being part of a community (\#7), we started to develop concrete future activities as follows.

\subsection{User Perspective - Getting the Method Right is as Important as the Content}

Starting with the learning material, especially practitioners emphasized that $e$-books worked best. Videos complement the content. Furthermore, we received the feedback that 60 minutes videos are too long. They should be cut into smaller pieces and therefore more individual topics. One participant suggested using interactive videos. This person referred to an reference which includes interposed questions for checking the transferred knowledge, asking participants to write down what key facts they kept in mind, and formulating questions for the upcoming classroom.

Discussing the (virtual) classroom, all participants laid out that multiple media should be offered to keep the attention. Live pictures from all participants and a compulsory introduction from everyone (if possible, an in-person meeting at the beginning of the training) should bring virtual training closer to reality. With its playful competition among participants, all participants praised the integration of game-based learning units. However, so the tenor, most lecturers are still hesitant in creating digital learning content (Sect. 2).

Community building in a flipped classroom is one of the biggest challenges we observed in our survey (Sect. 4). Taking this perception seriously, conducting break-out sessions in smaller groups and sharing the results with all classmates is a valid alternative.

Students revealed that interactions with the practitioners are highly appreciated. Their examples from work should be an integrative part of each classroom. But in the end, so another student, only hard facts that are relevant for the exam count.

Finally, we discussed the length of the flipped classroom sessions. In line with typical face-to-face classrooms, we came up with a maximum duration of $90 \mathrm{mi}$ nutes. According to a final comment, performing full day online workshops is not efficient as such a long sessions demotivates.

\subsection{Lecturers - Developing New Soft Skills Beyond Mere Knowledge Transfer}

Regarding having a motivated lecturer, this criterion lost importance due to the concept of flipped classroom training because most knowledge is transferred before the training (Sect. 4). This should be special in comparison to "classical" face-to-face classrooms where most knowledge still flows in the classroom itself. Thus, motivated lecturers may stay important before and even after the training for the latter kind of learning, but not for flipped classrooms.

Furthermore, stated by a participant, "the spark does not fly so easily”. In other words, the lecturers' evident tension, body language, and emotions become harder to read for the participants, compared to traditional classroom situations. Thus, lectures have to motivate their participants more by "pure" content, but also have to get used how to be "present" in virtual classrooms. 
Some students stated that they feel more reluctant in flipped classrooms to break the ice by asking the first question. However, one practitioner suggested defining a "champion" for each topic, guys who prepared such question, might help when the icebreaker question fails to arrive from the audience.

\subsection{Technology - Setting the Scene Properly When Rotating to the NEW}

One participant stated that IT has to work noiselessly. In line with Ernst et al [43], he/she assumed that the full range of IT capabilities often remains "fuzzy" for a number of lecturers and participants. Another participant said that "leveraging IT is always about trust." It is not easy to build this up, especially for tech-averse lecturers, and it can be destroyed even faster once it has been established. Summarizing our discussion, IT sets the scene for flipped classrooms. There is no second chance to create a first good impression when rotating to the NEW. Additionally, the first good one will not last long if severe inconveniences occur.

Furthermore, lecturers need to be prepared for IT incidents by running multiple tests under different circum-stances before the sessions. This might even include a failure of the online connection. In this case, lecturers may use their mobile phone as a hotspot. Thus, lectures have to become more tech-savvy themselves or, in case of doubt, so another comment, lecturers should have a tech-savvy colleague in the wings to support them.

For a few German universities that had implemented a digital concept before the COVID-19 pandemic, flipped classrooms went well in recent months, because they could continuously improve their offerings, based on their own experiences [44]. The students are motivated, have adapted to online classrooms quickly, learn in a virtual community, ask questions in chats, and receive feedback from lecturers and classmates online. However, the digital skills of the students had been developed during their higher education. They did not developed those skills earlier at school. We considered in our discussion that digital learning should start at school and self-guided learning as well.

\section{Discussion and Conclusion}

Using an SAP S/4HANA lecture at university as our case example, the objective of this article was to contribute to more user-centric flipped classrooms by developing a list of the requirements criteria from the perspective of different user groups. Accordingly, we asked practitioners and students about both their expectations before the training and their experience afterwards.

We came up with a bundle of differences between practitioners and students (Table 2). Practitioners highlighted self-contained learning at their own pace. By contrast, students asked for motivated lecturers to give direction. It is not important, however, for students that lecturers devote attention to them. For their part, practitioners want to ask detailed questions from their work. In driving interactivity, both practitioners and students responded that switching on the camera is a quick and easy win. Finally, both types of learners drew attention to the importance of how technology is applied. IT quality and ease of use were evaluated as a major prerequisite for successful flipped classrooms. Accordingly, lecturers should be trained to avoid IT incidents.

For research purposes, our requirements analysis is a rigorous starting point for making flipped classroom training sessions more user centric. Our method mix (Sect. 3) contributes to a comprehensive requirements analysis. In comparison to Kwon and Woo [8] and Bicen and Taspolat [30], we strengthen the lecturer perspective by examining two different groups of learners: In comparison to Oeste et al. [6] as well as Nederveld and Berge [25], our list of the requirements criteria provides hands-on advice for practice helping lectures making their trainings more interactive.

Our research reveals several avenues for future research: Especially when applying our demographic data characteristics (Sect. 3), the results should become more facetted by a broader and larger sample. This would be especially true for future analyses about the age of training participants and well-received kind of trainings.

Applying more sophisticated models such as the Technology Acceptance Model or the IS Success Model may help to improve flipped classroom trainings beyond our work. Finally, we focused on a flipped classroom training at a University of Technology. Results from other academic disciplines such as medicine (with more hands-on experiments needed) or psychology (where direct contacts with human beings are essential) would drive a more balanced requirements analysis.

Another avenue for research is to examine the impact of our list approach. An evaluation should indicate whether our findings could be translated into specific actions. We will go on with our work developing specific design guidelines that give lecturers hand-on advice to improve their trainings.

Last, but not least, we will continuously update our results, as the pace of e-learning is high and there are likely to be other unpredictable developments in the future. Whatever the case, our results are a current snapshot which yields insights into new learning approaches. 


\section{References}

[1] K. Mowbray and G. Dick, "Perceptions of ELearning in Organizations: An Empirical Study on the Effects of Gender Age, Duration of Employment, and Managerial Level," AMCIS Proceedings, vol. 9, pp. 1513-1523, 2003. [Online]. Available: https://aisel.aisnet.org/cgi/viewcontent.cgi ?article $=1656 \&$ context $=$ amcis2003

[2] H. Steinbeck, J. Matthiessen, and G. Vladova, "Student Learning Behaviour in the Digital Age," ICIS, vol. 40, pp. 1-9, 2019. [Online]. Available: https:// aisel.aisnet.org/cgi/viewcontent.cgi? article $=1452 \&$ context $=i$ icis2019. .

[3] D. Renner, S. Laumer, and T. Weitzel, "Effectiveness and Efficiency of Blended Learning - A Literature Review," AMCIS, vol. 20, pp. 1-13, 2014. [Online]. Available: https://aisel.aisnet.org/cgi/viewcontent.cgi ?article $=1286 \&$ context $=$ amcis2014 .

[4] B. Schenk and L. Hoxhaj, "Challenges in Switching to Blended Learning Environments: An Analysis of Students Attitudes and Performance," ICIS, vol. 40, pp. 1-15, 2019. [Online]. Available: https:// aisel.aisnet.org/cgi/viewcontent.cgi? article $=1450 \&$ context $=$ icis2019.

[5] A. Alammary, A. Carbone, and J. Sheard, "Blended Learning in Higher Education: Delivery Methods Selection," ECIS Proceedings, vol. 24, pp. 1-13, 2016. [Online]. Available: https://aisel.aisnet.org/cgi/ viewcontent.cgi article $=1148 \&$ context $=$ ecis2016_rp.

[6] S. Oeste, K. Lehmann, A. Janson, and J. M. Leimeister, "Flipping the IS Classroom Theory-Driven Design for Large-Scale Lectures.," ICIS, vol. 35, pp. 1-12, 2014.

[7] P. V. Roehling, "Student Reactions to and the Effectiveness of the Flipped Classroom Across Learning Domains," in Flipping the College Classroom, P. V. Roehling, Ed., Cham: Springer International Publishing, 2018, pp. 15-43.

[8] J. Kwon and H. Woo, "The Impact of Flipped Learning on Cooperative and Competitive Mindsets," Sustainability, vol. 10, no. 2, p. 79, 2018, doi: 10.3390/su10010079.

[9] R. A. Alali, "Effectiveness of a Proposed Program in Developing Practices and Modifying Beliefs of Practitioner Teachers About the Flipped Classroom," SAGE Open, vol. 10, no. 2, 215824402091977, 2020, doi: $10.1177 / 2158244020919775$.
[10] H. A. Simon, The Science of the Artificial, 3rd ed. Cambridge, Mass: MIT Press, 1996. [Online]. Available: http://search.ebsco host.com/login.aspx?direct=true\&scope $=$ site $\& \mathrm{db}=$ nlebk\&db=nlabk\&AN $=49230$.

[11] J. G. Walls, G. R. Widmeyer, and O. A. El Sawy, "Building an Information System Design Theory for Vigilant EIS," ISR, vol. 3, no. 1, pp. 36-59, 1992, doi: 10.1287/isre. 3.1.36.

[12] A. R. Hevner, S. T. March, J. Park, and S. Ram, "Design Science in Information Systems Research," MIS Quarterly, vol. 28, no. 1, pp. 75-105, 2004, doi: 10.2307/ 25148625.

[13] J. Vom Brocke, R. Winter, A. Hevner, and A. Maedche, "Accumulation and Evolution of Design Knowledge in Design Science Research - A Journey Through Time and Space," JAIS, vol. 21, no. 3, pp. 520-544, 2020.

[14] S. Gregor and A. R. Hevner, "Positioning and Presenting Design Science Research for Maximum Impact," MIS Quarterly, vol. 37, no. 2, pp. 337-355, 2013. [Online]. Available: www.jstor.org/stable/43825912

[15] K. Peffers et al., "The Design Science Research Process: A Model for Producing and Presenting Information Systems Research," DESRIST Proceedings, pp. 83106, 2006.

[16] AIS, Senior Scholar's Basket of Journals. [Online]. Available: https://aisnet.org/ page/SeniorScholarBasket (accessed: Jul. 14 2020).

[17] AIS, Conferences. [Online]. Available: https://aisnet.org/page/Conferences (accessed: Jul. 14 2020).

[18] J. Webster and R. T. Watson, "Analyzing the Past to Prepare for the Future: Writing a Literature Review," MIS Quarterly, vol. 26, no. 2, pp. xiii-xxiii, 2002. [Online]. Available: www.jstor.org/stable/4132319.

[19] S. K. Davis, Why Flipped Classrooms Work. [Online]. Available: https:// pro.harman.com/insights/enterprise/ education/why-flipped-classrooms-workand-how-technology-can-help/ (accessed: June 4th 2020).

[20] Flipped Learning Network, "A community resource brought to you by the Flipped Learning Network," 2020. Accessed: June 4th 2020. [Online]. Available: https:// flippedlearning.org/.

[21] Panopto, Flipped Learning: Coming Soon To Your Office. [Online]. Available: 
https://www.panopto.com/blog/flippedlearning-coming-soon-to-your-office/ (accessed: June 4th 2020).

[22] Yale Poorvu Center for Teaching and Learning, Flipped Classroom. [Online]. Available: https://poorvucenter.yale.edu/ FlippedClassroom (accessed: Jun. 4 2020).

[23] J. Rowley and F. Slack, "Conducting a literature review," Manag. Res. News, vol. 27, no. 6, pp. 31-39, 2004.

[24] IEEE, IEEE Recommended practice for software requirements. New York, 1998.

[25] A. Nederveld and Z. L. Berge, "Flipped learning in the workplace," $J$ Workplace Learn, vol. 27, no. 2, pp. 162-172, 2015, doi: 10.1108/JWL-06-2014-0044.

[26] E. Loukis, S. Georgiou, and K. Pazalo, "A Value Flow Model for the Evaluation of an E-Learning Service,” ECIS Proceedings, pp. 370-382, 2007.

[27] A. M. Lokman, T. Yamanaka, P. Lévy, K. Chen, and S. Koyama, Eds., Assessing the Impact of "More-Flexible" Learning as Part of a Study Program, 2018.

[28] I. Sommerville, Software engineering. Boston: Pearson, 2016. Accessed: Jul. 132020.

[29] P. V. Roehling, Ed., Flipping the College Classroom. Cham: Springer International Publishing, 2018.

[30] H. Bicen and A. Taspolat, "Students' Views on the Teaching Process Based on Social Media Supported Flipped Classroom Approach," BRAIN, vol. 10, no. 4, pp. 115144, 2019, doi: 10.18662/brain/o8.

[31] J. Coady and T. Berg, "Flipping the IS Classroom: Technology Exclusion in a Digital Age," ICIS, vol. 37, pp. 2-7, 2016. [Online]. Available: https://aisel.aisnet.org /cgi/viewcontent.cgi?article $=1127 \&$ context=icis2016.

[32] E. Blair, C. Maharaj, and S. Primus, "Performance and perception in the flipped classroom," Educ Inf Technol, vol. 21, no. 6, pp. 1465-1482, 2016, doi: 10.1007/s10639015-9393-5.

[33] A. Tashakkori and C. Teddlie, Eds., Handbook of Mixed Methods in Social \& Behavioral Research: Los Angeles, London, New Dehli, Singapore, 2003.

[34] SoSci Survey, SoSci Survey - the Solution for Professional Online Questionnaires. [Online]. Available: https://dinus.ac.id/ repository/docs/ajar/SommervilleSoftware-Engineering-10ed.pdf.

[35] C. M. Judd, Resaearch methods in social relations. London: Holt, 1991.
[36] D. L. Streiner, "Starting at the Beginning: An Introduction to Coefficient Alpha and Internal Consistency," J. Pers. Asses., vol. 80, no. 1, pp. 99-103, 2003.

[37] E. B. Kim, "Student Characteristics As Predictors For Online Course Success," PACIS Proceedings, pp. 1-10, 2011. [Online]. Available: https://aisel.aisnet.org/cgi/ viewcontent.cgi article $=1095 \&$ context $=$ pacis2011.

[38] Y.-T. Lin, "Impacts of a flipped classroom with a smart learning diagnosis system on students' learning performance, perception, and problem solving ability in a software engineering course," Comput. Hum. Behav., vol. 95, pp. 187-196, 2019, doi: 10.1016/j.chb.2018.11.036.

[39] H. N. Mok, “The Flipped Classroom,” JISE, vol. 25, no. 1, 2014. [Online]. Available: https://aisel.aisnet.org/cgi/viewcontent.cgi ?article $=1103 \&$ context $=$ jise.

[40] T. Acton, S. Hill, and M. Scott, "E-education,” BLED Proceedings, vol. 18, pp. 1-11, 2005. [Online]. Available: https:// aisel.aisnet.org/cgi/viewcontent.cgi? article $=1071 \&$ context=bled2005.

[41] H. Awang, Z. Aji, and W. R. S. Osman, "The Moderating Effect of Workload in Determining the Continuous Usage of Virtual Learning Environment amongst School Teachers," PACIS Proceedings, vol. 22, pp. 1-15, 2018. [Online]. Available: https:// aisel.aisnet.org/cgi/viewcontent.cgi? article $=1050 \&$ context $=$ pacis2018 .

[42] Y. Dang, Y. Zhang, S. Ravindran, and T. Osmonbekov, "Examining Student Satisfaction and Gender Differences in TechnologySupported, Blended Learning," JISE, vol. 27, no. 2, pp. 119-131, 2016. [Online]. Available: https://aisel.aisnet.org/cgi/ viewcontent.cgi ?article $=1069 \&$ context $=$ jise

[43] C.-P. H. Ernst, K. Wedel, and F. Rothlauf, "Students Acceptance of E-Learning Technologies: Com," AMCIS, vol. 20, pp. 17, 2014. [Online]. Available: https:// aisel.aisnet.org/cgi/viewcontent.cgi? article $=1630 \&$ context $=$ amcis2014.

[44] C. Li and F. Lalani, The COVID-19 pandemic has changed education forever. [Online]. Available: https://www.weforum. org/agenda/2020/04/coronaviruseducation-global-covid19-online-digitallearning/ (accessed: Jun. 18 2020). 